\title{
Biomechanical Properties of Rattan Cane in the Design and Fabrication of Prosthetic Foot
}

\author{
Kelechi D. Kelechi ${ }^{*}$, Gideon I. N. Ndubuka#, Kingsley C. Onwukamuche ${ }^{3 *}$, Michael C. Ofoegbu ${ }^{4}$ Ugochi $^{2}$ \\ C. Elueke ${ }^{5}$, Alice C. Igwe ${ }^{6}$, Wilson C. Okafor ${ }^{7}$, Chioma C. Okey-mbata ${ }^{8}$, Jervas Ekezie9 .

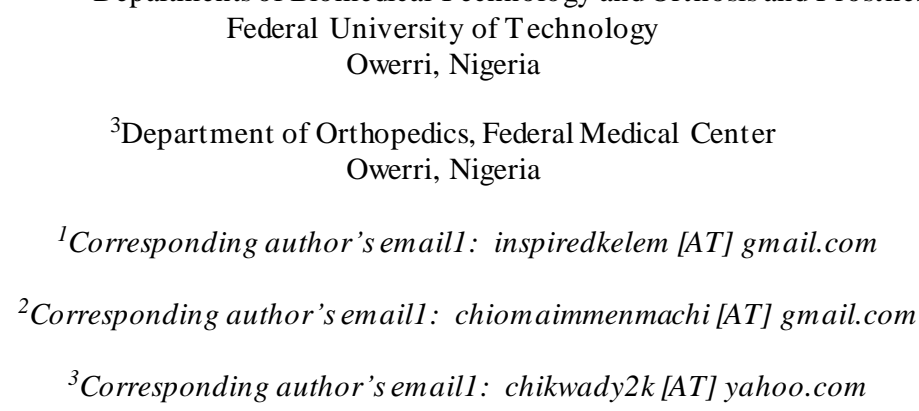

\begin{abstract}
In designing prosthetics for amputees, quality and quantity of materials determine device tensile, flexural, extension and compression strength as well as energy distribution when load is applied. Biomechanical properties contribute in combination to any device longevity and resolution force effect to gait expression. Four different dry rattan canes were sampled and subjected to biomechanical analysis, and sample 3 had highest tensile strength with ultimate tensile strength of $11.5 \mathrm{~N} / \mathrm{mm}^{2}$ revealed when load at break of $668.18 \mathrm{~N}$ applied, and modulus $1033.90 \mathrm{MPa}$ with ductility of $7.33 \mathrm{~mm}$ were resultant. While average ultimate tensile strength of $8.68 \mathrm{~N} / \mathrm{mm}^{2}$ was sustained by load at break of $396.66 \mathrm{~N}$, modulus of $1119 \mathrm{MPa}$ and ductility of $9.5 \mathrm{~mm}$ was confirmed of rattan cane. Highest flexural strength of $34.43 \mathrm{~N} / \mathrm{mm}^{2}$ resulted from load at break of 32.82N, modulus $255.65 \mathrm{MPa}$ and elongation of 66.81mm was dictated of sample 3, and an average Flexural strength of $26.4 \mathrm{~N} / \mathrm{mm}^{2}$ occurred when load at break of $16.04 \mathrm{~N}$, modulus $229.16 \mathrm{MPa}$ produced elongation (ductility) of $55.1 \mathrm{~mm}$ on rattan cane. The highest load resistance was shown by sample 3 at compressive strength of 8.79MPa when on load at break of 330N, modulus 622.53MPa resulted. While sample 4 had the highest compressive strength of 9.94MPa when load break at 309N exerted modulus 283.14MPa. Gait analysis revealed terminal swing and heel strike of chosen height $8 \mathrm{~cm}$ and deformity $0 \mathrm{~cm}$ while early and mid stance of $0.3 \mathrm{~cm}$ and $7.7 \mathrm{~cm}$ were respectively for deformity and height.
\end{abstract}

Keywords ---- Rattan Cane, Biomechanical Properties, Fabrication, Prosthetic Foot

\section{INTRODUCTION}

Man-made Prosthetic devices are used for the replacement of missing body parts popular of which is limb of an amputee sequel to disease condition incident or accident. Many of such artificial are fashioned to meet theneeds and satisfy natural fruition level of human lost part that is replaceable. Therefore the convenience, pattern of lifestyle, limitation within microenvironment or sustainable major environment of adaptation by an individual amputee contribute immensely to the discomfort experience at the replaced lost part remains. While type of prosthetics chosen and biomechanical composition of the biomaterial used in the device influence design and fabrication. Hence the ability of an amputee to main tain day to day activities is as the foot allows the amputee freedom to ambulatory gait adapted [1]. To each type of prosthetics the layout of fabrication though may differ depending on biomechanics of material particularly for prosthetic foot. It is expected that psycho-physiological and anatomical freedom be harnessed by each user. Major activities of the amputee when compensated by principles of design, means that the pattern of fabrication engraved as a proviso takes credit in the type of material for convenience and must meet the acceptance of the amputee without undermining the extent of lost and pos sible stigma.

Rattan canes obtained fromthes temof the rattan plant have received consideration because of its strength, light weight, durability and other mechanical properties first realized in structural engineering such as bridge construction and household 
furniture design [2] and others. Also rattan cane has specialqualities gained from the biochemical structural arrangement that formed the physical factors apparent. This may have been reason els ewhere for its use irrespective of the level of dryness [3]. When subjected to relative amount of heat rattan cane shows ductility such that it can easily be realigned and readjusted into several structural design shapes without structural molecular strain or damage [4]. Studies have shown the pliability of rattan cane as distinct engineering material derived fromlinearexpansive- like quality [5].

Rattan cane exists as relatively durable and elastic slim wood often used in furniture industry for the production of hou sehold utensils and as special commodity made from handicraft industries [6]. Most Nigerian rural communities where rattans grows as wild plant harvest the stem for commercial purposes and depend on it to majorly boast their socio economic wellbeing and improve standard of living [7-8]. In the ancient African setting, rattan is a major raw material for virtually all home utensils [9]. As a forest plant the slimy wood is usually processed for mechanized farming as well as craft works for sustainable income [10-11].The cane is common among many communities and the most useful and popular part of rattan can easily be processed for use either as raw material or shaped into furniture [12-15]. Also the leaves, roots and fruits are sometimes used by rural farmers for medicinal purposes. About $20 \%$ of the four popular rattan species in West Africa are found useful in severalforms of community resource values, while the remaining $80 \%$ are counted among lost value due to poor processing. This als o has resulted in breakage and unsatisfactory utilization of the mechanical properties, while the biological and molecular rarity is a ques tion of underdevelopment of the co mmunity of origin [15-17].

Therefore, in selecting a prosthetic foot for an amputee, biomechanical and mechanical properties as tensile, compressive strength, and resistance to corrosion were considered. Also durability which influence cost efficiency was regarded [18] important match with the desire of the amputee. This is because an ideal and classed prosthetic foot should be able to perform Range of Motion (RoM) as; dorsiflexion range of motion up to an angle of $20^{\circ}$, eversion movement through a $20^{\circ}$ angle (ankle) with $117 \%$ energy return efficiency. These can be achieved when the molecularcomposition of the prosthetic foot and the principal mechanis m of fabrication are considered [19]. In addition to the attributes stated, prosthetic feet should also be readily accessible, not difficult to mend, easy to do $n$ and doff, flexible, easy to change and remain affordable [1].

Good understanding of foot biomechanics is important to the choice of basic material for a particular prosthetic. A device effective and efficient functional property is not dependent on alignment alone. The durometer of the heel cushion, width of the keel may influence flexibility of the keel. But length of the toe lever-arm, and fit of the pros thetic foot within the shoe are possible in design and fabrication. Therefore rattan cane mechanical properties have proved good in design works particularly in areas where load and stress are of fundamental consideration [6 and18]. Also the rattan cane size and the pliability can be related to molecular arrangement that form the stem stuff. Other molecular characteristics of material for prosthetic foot are prompt and smooth articulation with the suspension systemused. That is the type of socket design and shaped for opposite material interfacing composition and the residual limb tis sue, and the pylo nability to in or let out compressive forces that support the rigidity of the heel and forefoot keel [20].

The mechanical property of prosthetic material determines the weight bearing ability, and this property has been exhibited by rattan cane in furniture making [13-14]. Though that the contortion of the foot is controlled by its stiffness. This consequently influences absorption, conservation and discharge of energy as work is done partly over load [21]. A prosthetic foot structured and patterned is to operate under load. It is expected to support directional ripples while at gait performance and hazy characteristic stylish motions in stride. When it is fashioned to sustain running and dance, such fabricate is superior. The mechanical properties of rattan cane may vary supportively to include springing; compactness, contractile, and extensor. These are often said to sustain gait cycle and give understanding to prosthetic period of modification, optimal operation and shelf life. Almost all properties in design material science have been found basic, and were extended to shoe heel height and shape during motion [22].

Shock is a vital characteris tic of work done on load and theretention or dis sipation by any pros thetic feet. It is also the function of biomechanical structure of biological or chemical of material type. Several types of materials have been found useable in medical rehabilitation technology because of advances in material science and biology [23] without consideration on rattan cane. These include prosthetic foot made of titanium, stainless steel, aluminum, polymer, plant and animal composites. Although, for the foot connecting adapters. Other materials like leather and latex [24] and carbon fiber [23] are also considered impres sive.

Therefore, in consideration of the spring property and other biomechanical characteristics, rattan cane is viewed as biomaterial in medical rehabilitation technology application. Consequently, it is considered for the design and fabrication of 
prosthetic feet. The biomechanical properties were searched for and were related to the efficiency, durability and cost effectiveness of prosthetic foot made fromrattan cane.

\section{MATERIALS AND METHODS}

The biomechanical test sought to determine the tensile strength over load and compression resistance of the entire device again st pressure to spring. All sample pieces (labeled sample 1to 4) of rattan canes were reduced to $10 \mathrm{~mm}$ from the natural $20 \mathrm{~mm}$ size to ens ure proper alignment into the Instron Ultimate Testing Machine (Model3369). The choice of four samples for the tests was considered based on the fact that there is su spicion of rattan cane to show difference in strength and compression at different weight and dryness rather than specie. Therefore biomechanical analysis considered on rattan cane excludes the molecular structure arrangement and energy conservation within bonds.

\subsection{Instron Ultimate Testing Procedures}

Instron machine was preferred because it has the capability to test for mechanical properties of several material objects when the enabling accessories are involved. It has a running time of 4 hours, 44 minutes to es timate compression, torsion, fatigue, hardness, tension, and flexure tests among others of material objects. Strain was analyzed from $\varepsilon=\mathrm{d} L$ and $\sigma=$ F/A gave stress. Therefore, in the machine was appropriated Young's Modulus as is delivered by $\mathrm{E}=\sigma / \varepsilon$.

The es sential characteristics of material may vary consistently even with same type, and this depends on constitution. This can be explained by an equation that addresses stress and strain relationships. The equivalent stress to associated equivalent strain can beexplained by von Mises yield test [25]

$\sigma_{\mathrm{eq}}=\frac{1}{2}\left[\left(\sigma_{1}-\sigma_{2}\right)^{2}+\left(\sigma_{2}-\sigma_{3}\right)^{2}+\left(\sigma_{3}-\sigma_{1}\right)^{1 / 2}, \varepsilon_{\mathrm{eq}}=\frac{1}{1+v} \frac{1}{\sqrt{2}}\left[\varepsilon_{1}-\varepsilon_{2}\right)^{2}+\left(\varepsilon_{2}-\varepsilon_{3}\right)^{2}+\left(\varepsilon_{3}-\varepsilon_{1}\right)^{2}\right]^{1 / 2}$

Where $\sigma_{\mathrm{i}}$ and $\varepsilon_{\mathrm{i}}$ are the main stres ses and strains, respectively, and $v$ is the Pois son ratio.

Consequently material properties under stresses produce shear strain may have essential equation to the relationship thus; $\sigma_{\mathrm{eq}}=\mathrm{f}\left(\varepsilon_{\mathrm{eq}}\right)[26]$.

Since the rattan cane samples were not completely dried at onset of study, factors like volume of fluid and the consequent hydrostatic pressure are expected to be analyzed by the machine thus;

$p=\frac{\left(\sigma_{1}+\sigma_{2}+\sigma_{3}\right)}{3} ; \Theta=\varepsilon_{1}+\varepsilon_{2}+\varepsilon_{3}$

As there exist hydrostatic pressure and volume change during analysis. Fromequation $1, \sigma_{1}=\sigma_{2}=\sigma_{3}$, and in resolution $\sigma_{\mathrm{eq}}$ $=0$ and $\varepsilon_{\mathrm{eq}}=0$

Therefore, theestimation of tensile, compression and shear stresses serve as measure for elastic modulus (E). Elasticity defines the mechanical properties associated with object springing ability. As restoration force is proportional to elongation (stretch) and Hooke's law des cribed this in linear and nonlinear material. Hence, equations 1 and 2 have addressed stress - strain relationship to be linear throughout.

The machine was allowed to run throughout at a standard rate, condition and control specified by the manufacturer for the parameters required as follows;

\subsection{Tensile test}

The load pointer was adjusted to zero using the initial setting knob.

The dial gauge and specimen were secured to the ultimate testing machine in order to measure elongation of small amounts.

The sample was attached between the upper and middle cross head of the machine and the automa tic graph recording systemwas set appropriately.

The machine started for full circle and readings obtained were recorded as each sample loaded is followed gradually by another. Elongation is also noted until the failure of each sample. 


\subsection{Compression Test}

The samples were aligned (each) at the center, between two compressive plates with the mid -point of the moving head vertically above the center of the samples.

Load is applied on the samples by moving the movable head.

The movable head applies load on the samples and the corresponding change were recorded. Load was applied until the sample failed.

To distinguish compressive strain from plastic work, rattan cane behavior should be seen as arbitrary. Hence initial strain and second divergent strain though invariant are represented as $I_{1}, J_{2}$ while the secant elas tic bulk modulus $K_{s}$ and elastic shear modulus $\mathrm{G}_{\mathrm{s}}$ give [27-28]

$\left.\mathrm{I}_{1}=\varepsilon_{1}+\varepsilon_{2}+\varepsilon_{3}=\Theta, \sqrt{\mathrm{J}} 2=\frac{1}{\sqrt{2}}\left[\varepsilon_{1}-\varepsilon_{2}\right)^{2}+\left(\varepsilon_{2}-\varepsilon_{3}\right)^{2}+\left(\varepsilon_{3}-\varepsilon_{1}\right)^{2}\right]^{1 / 2}$

\subsection{Flexural Test (3 Point Bend Test)}

Each sample was placed on two support anvils. Force was applied directly on the sample between the support an vils. The applied force was continually increased until the samples break. The increasing amount of force and amount of load at each breaking point by the machine were recorded.

Supposing that total behavior of rattan lies as a function of $\mathrm{I}_{1}$ and $\mathrm{J}_{2}$, and is described by [29-30]

$\mathrm{K}_{\mathrm{s}}=\mathrm{K}_{\mathrm{s}}\left(\mathrm{I}_{1}, \mathrm{~J}_{2}\right)$, Gs $=\mathrm{Gs}\left(\mathrm{I}_{1}, \mathrm{~J} 2\right)$

4

This applies in the Instron machine, and if constutitive equation of an arbitrary material in the engineering space is considered and the curves are applied, $T_{V}$ represents elas tic strain energy stored for volume changes, $T_{D}$ available elastic strain energy density while plastic work coexist, equations 1 and 2 still hold for isotropic material. To analyze $T_{V}$ and $T_{D}$ quantities of rattan cane means that dilatational strain energy density $T_{V}$ is the ultimate elastic and $T_{D}$ estimates elastic distortional strain energy density, and these coexist with plastic work. Therefore as rattan cane failed on compression plastic flow point, either $T_{V}=T_{V}, o$ or $T_{D}=T_{D}, o$, where $T_{V}, O, T_{D}, o$ are the critical elas tic strain energy densities [31].

Failure can be determined in two ways (i.e. dilatational and distortional), and nonlinear material can be generally captured by [32-33]

$\mathrm{T}_{\mathrm{V}}=\int_{0}^{\mathrm{I} 1, \mathrm{O}} \frac{1}{2} \mathrm{~K}_{3}\left(\mathrm{I}_{1}, \mathrm{~J}_{2}\right) \mathrm{dI} \frac{2}{1}=\mathrm{T}_{\mathrm{V}, \mathrm{O}}$ for failure by cleavage, $\mathrm{T}_{\mathrm{D}}=\int_{0}^{\mathrm{J} 2, \mathrm{o}} 2 \mathrm{Gs}\left(\mathrm{I}_{2}, \mathrm{~J}_{2}\right) \mathrm{DJ} \mathrm{J}_{2}=\mathrm{TD}$, O for failure by slip $\quad 5$

This defines T-criterion (Andrianopoulos and Boulougouris 1994), Failure by cleavage (brittle fracture) occurs when $\mathrm{T}_{\mathrm{V}}$ reaches a critical value $\mathrm{T}_{\mathrm{V}, 0}$ and failure by slip (plastic flow) occurs when $\mathrm{T}_{\mathrm{D}}$ reaches a critical value $\mathrm{T}_{\mathrm{D}, 0}$ for all materials .

\subsection{Methods of Rattan Cane Prosthetic Foot Fabrication}

The fabrication of a dynamic response prostatic foot for lower limb transfemoral, transtibial, knee dis articulation, and other forms of amputees are common. It requires the unders tanding of biomechanics, bioenergetics and performance in gait. The tensile and compression forces sheared from patient's weight among others allow for step by step directional motion that is a derivative. Quality of materials and design pattern were considered prime factors that can militate against efficiency, ductility, and robustness of the devicefabricated. Considerably, material turf, molecular characteristics methods of procession may constitutively affect the longevity of the device. Hence biomechanical properties of material and bioefficiency were primary in the prosthetic footdesign and fabrication.

\subsection{Gait Analysis}

The patient gait testing with the device was carried out to check the ability of the device to withstand load and Shock. Selected patients were amputees who have been on gait activities with another type of device prior to this performance test with the new fabricate at foot size of $8 \mathrm{~cm}$.

Five patients recruited were transtibial amputees using a Trans tibial Prosthesis with SACH foot for the past 6 months. They have no obvious diagnosable disease condition and were ps ychophysiological balanced overtime. 
Each patient SACH foot was disconnected and the Rattan foot fitted in position. Patients were videoed with a steadily and stably camera, as he or she ambulates along a parallel walking beam. The video was zoomed on a computer screen, and every stepby step motion and each step accessed of gait were analyzed.

To understand and analyze gait with foot prosthesis requires that standard method of testing be applied. Such is that which meas ures s pringy retained energy properties in an exerted path by load. Assuming that the prosthetic foot has total strain energy density $T$, the resultant gait activities will be trans lated fromactual stresses and strain s when weight on and off. Hence the equation which applies on principal stresses and strains of a material suffices and is thus [26], [34];

$\mathrm{T}=\frac{1}{2} \sum_{i-1}^{3} \int_{0}^{\sigma \mathrm{i}} \sigma \mathrm{i}(\varepsilon \mathrm{i}) \mathrm{d} \varepsilon \mathrm{i}$

Resulting in deviation and deformity characterized by both hydrostatic pressure and volume shape changes of rattan cane in part.

To ens ure validity and accuracy of the configuration of each slide, the prosthetic rattan foot length (Heel to Toe) was used as a reference or a buffer.

As the patient performs gait, the deviations in the footheight were meas ured with graduated Meter-rule in centimeters and recorded accordingly. Applying equation 3, Stres s is proportional to Strain over which hydrostatic pressure and volume changes characterized density. Therefore the Load (Patient weight) transferred to the prosthetic rattan cane foot is proportional to the Height deviations. These deviations are measurable values of the shock absorption.

\section{RESULTS AND DISCUSSION}

Four samples of rattan canes were selected based on the bio-rigged quality and physic-mechanical nature to weight and smoothness. It was observed that after rain rattan cane though partially dried did not soak water rather allow water to drain away. Consequently the bio-mechanical test results express values as follows;

\subsection{Tensile Test Result}

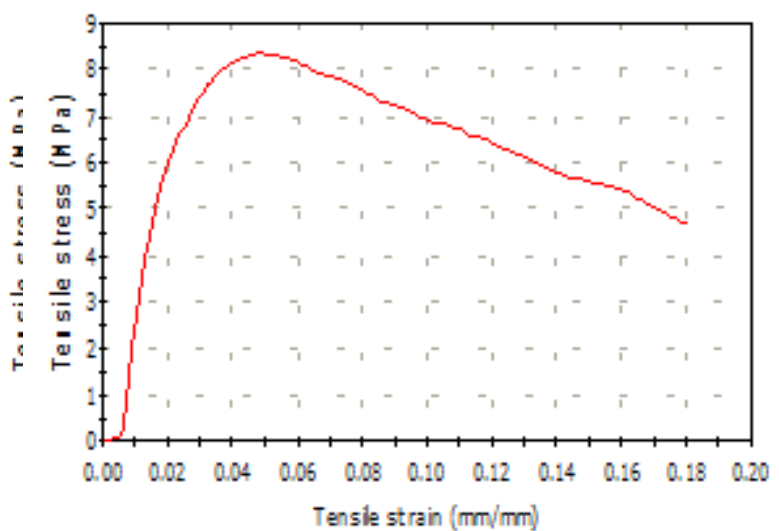

$\mathbf{A}$

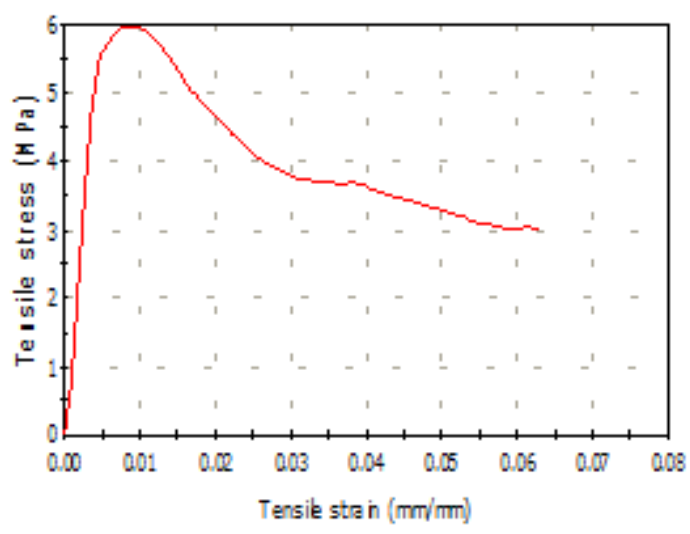

B 


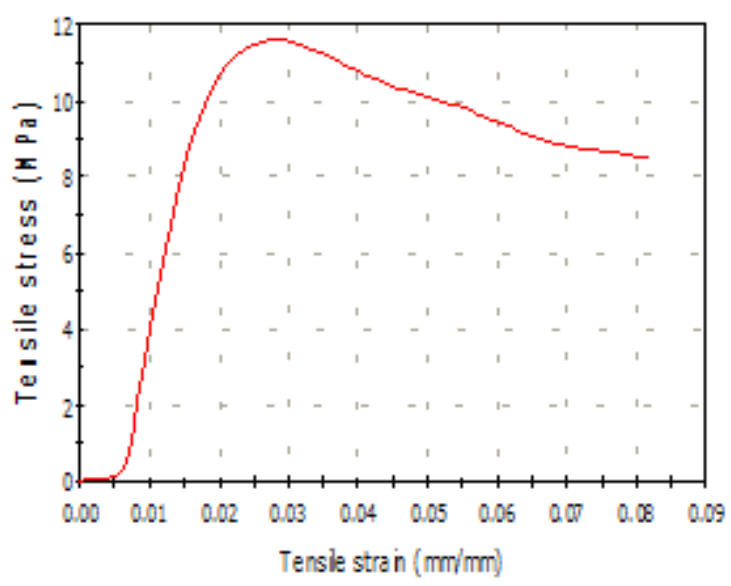

C

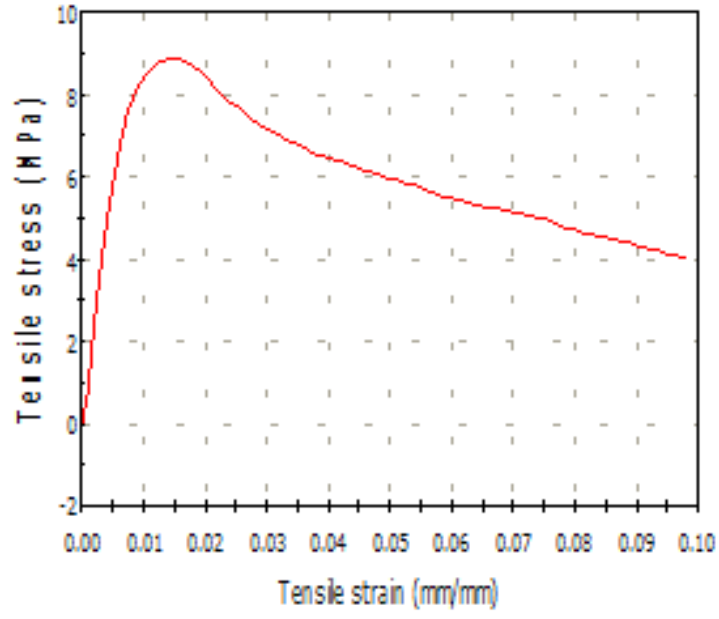

$\mathrm{D}$

Figure 1: A. Graph Showing Tensile Stress and Strain of Sample 1. It had UTS (tensile strength) of $8.35 \mathrm{~N} / \mathrm{mm}^{2}$, load at break of 367N, modulus 573.63MPa and elongation (ductility) of 16.25mm. B. Graph Showing Tensile Stress and Strain of Sample 2. Shows UTS of $6 \mathrm{~N} / \mathrm{mm}^{2}$, load at break of $236.6 \mathrm{~N}$, modulus $1433.71 \mathrm{MPa}$ and elongation (ductility) of $5.58 \mathrm{~mm}$. C. Graph Showing Tensile Stress and Strain of Sample 3. Revealed UTS of 11.5N/mm², load at break of 668.18N, modulus 1033.90MPa and elongation (ductility) of 7.33mm. D. Graph Showing Tensile Stress and Strain of Sample 4. Shows had UTS of $8.86 \mathrm{~N} / \mathrm{mm}^{2}$, load at break of $314.86 \mathrm{~N}$, modulus $1434.74 \mathrm{MPa}$ and elongation (ductility) of $8.83 \mathrm{~mm}$.

Table 1. Showing Load, Extension, Tensile Strain andStress at Break of the Samples

\begin{tabular}{|c|c|c|c|c|}
\hline Sample & $\begin{array}{c}\text { Load at Break } \\
(\text { Standard) } \\
(\mathrm{N})\end{array}$ & $\begin{array}{c}\text { Extension at Break } \\
(\text { Standard) } \\
(\mathrm{mm})\end{array}$ & $\begin{array}{c}\text { Tensile strain at } \\
\text { Break (Standard) } \\
(\mathrm{mm} / \mathrm{mm})\end{array}$ & $\begin{array}{c}\text { Tensile stress at } \\
\text { Break (Standard) } \\
(\mathrm{MPa})\end{array}$ \\
\hline 1 & 367.06070 & 16.25031 & 0.18056 & 4.67356 \\
\hline 2 & 236.67477 & 5.58328 & 0.06204 & 3.01344 \\
\hline 3 & 668.18036 & 7.33344 & 0.08148 & 8.50754 \\
\hline 4 & 314.86391 & 8.83344 & 0.09815 & 4.00897 \\
\hline
\end{tabular}


Table 2.Showing Energy at Break, Modulus, Load and Energy at Yield of the Samples

\begin{tabular}{|c|c|c|c|c|}
\hline Sample & $\begin{array}{l}\begin{array}{l}\text { Energy at Break } \\
\text { (Standard) }\end{array} \\
\text { (J) }\end{array}$ & $\begin{array}{l}\text { Modulus (Automatic) } \\
(\mathrm{MPa})\end{array}$ & $\begin{array}{l}\text { Load at Yield (Zero } \\
\text { Slope) } \\
\text { (N) }\end{array}$ & $\begin{array}{l}\text { Energy at Yield (Zero } \\
\text { Slope) } \\
\text { (J) }\end{array}$ \\
\hline 1 & 8.02920 & 573.63460 & 655.88499 & 1.87295 \\
\hline 2 & 1.75566 & 1433.71708 & 471.42857 & ----- \\
\hline 3 & 4.98099 & 1033.90968 & 903.5713 & ---- \\
\hline 4 & 4.13338 & 1434.74068 & 696.38710 & 0.66349 \\
\hline
\end{tabular}

Table 3. Showing Extension, Tensile Strain at Yield, Ultimate Tensile Strength and tensile extension at Break of the Samples

\begin{tabular}{|c|c|c|c|c|}
\hline Sample & $\begin{array}{c}\text { Extension at Yield } \\
\text { Zero Slope }) \\
(\mathrm{mm})\end{array}$ & $\begin{array}{c}\text { Tensile strain at Yield } \\
(\text { Zero Slope }) \\
(\mathrm{mm} / \mathrm{mm})\end{array}$ & $\begin{array}{c}\text { Ultimate } \\
\text { Strength } \\
\left(\mathrm{N} / \mathrm{mm}^{2}\right)\end{array}$ & $\begin{array}{c}\text { Tensile extension at } \\
\text { Break (Standard) } \\
(\mathrm{mm})\end{array}$ \\
\hline 1 & 4.33344 & 0.04815 & 8.35099 & 16.25031 \\
\hline 2 & ---- & 0.008 & 6.00 & 7.58328 \\
\hline 3 & ---- & 0.026 & 11.500 & 8.83344 \\
\hline 4 & 1.33359 & 0.01482 & 8.86668 & 8.834 \\
\hline
\end{tabular}

Table 4. Showing Final Area at Area Reduction and True Stress at Yield.

\begin{tabular}{|c|c|c|}
\hline s Sample & $\begin{array}{c}\text { Final Area at Area } \\
\text { Reduction } \\
\left(\mathrm{mm}^{2}\right)\end{array}$ & $\begin{array}{c}\text { True stress at Yield } \\
\text { (Zero Slope) } \\
(\mathrm{MPa})\end{array}$ \\
\hline 1 & 78.53982 & 8753081.39982 \\
\hline 2 & 78.53982 & ---- \\
\hline 3 & 78.53982 & ---- \\
\hline 4 & 78.53982 & 8998059.82947 \\
\hline
\end{tabular}

AverageUTS 8.68N/mm², load at break of 396.66N, modulus of 1119MPa and elongation (ductility) of $9.5 \mathrm{~mm}$.

Experimental Observation -Sample 3 has the highest UTS followed by sample 4, 1 and 2. The most ductile is sample 1 followed by 4, 3 and 2. The highest modulus (stiffness) is sample 4. 


\subsubsection{Flexural Test Result}

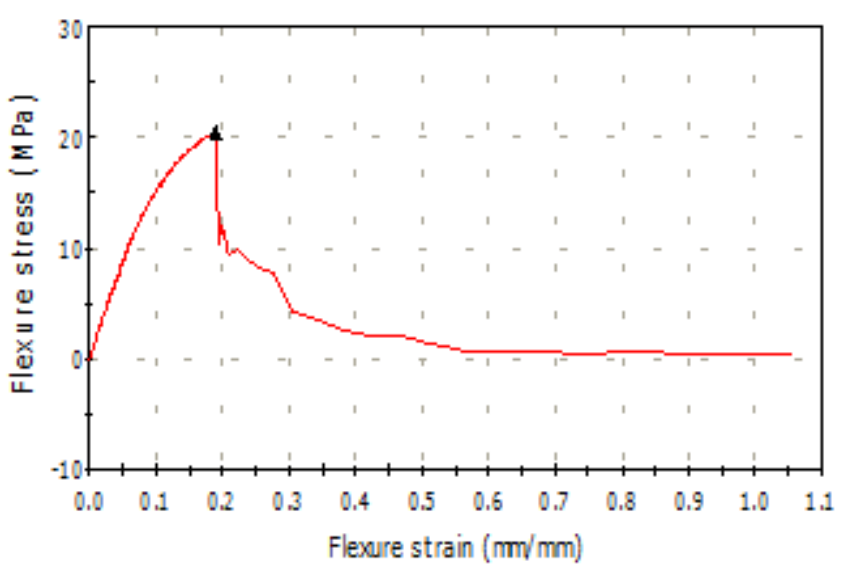

A

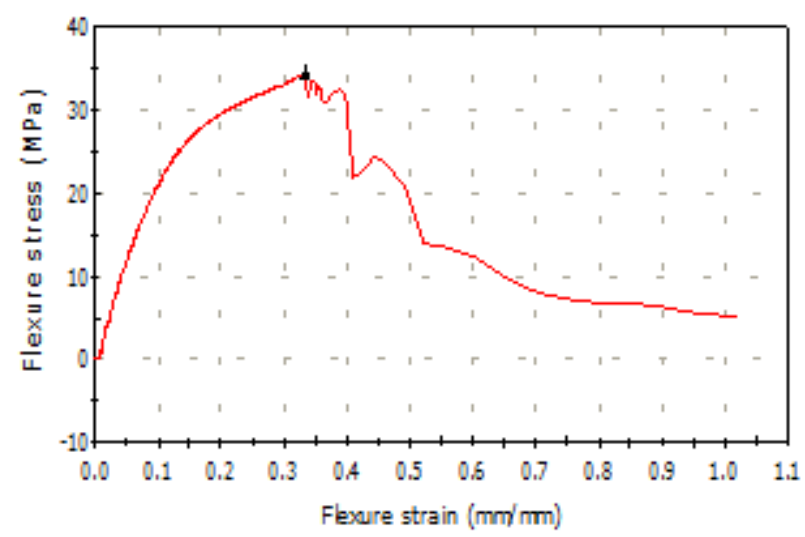

C

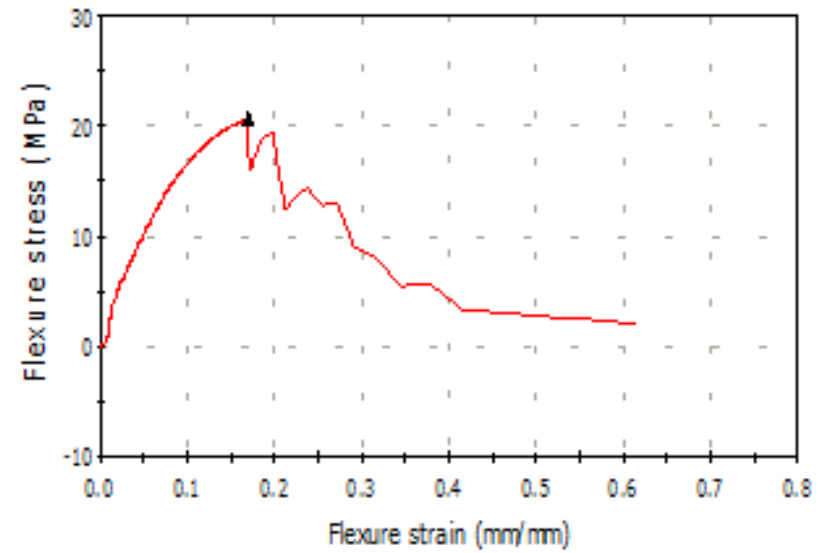

B

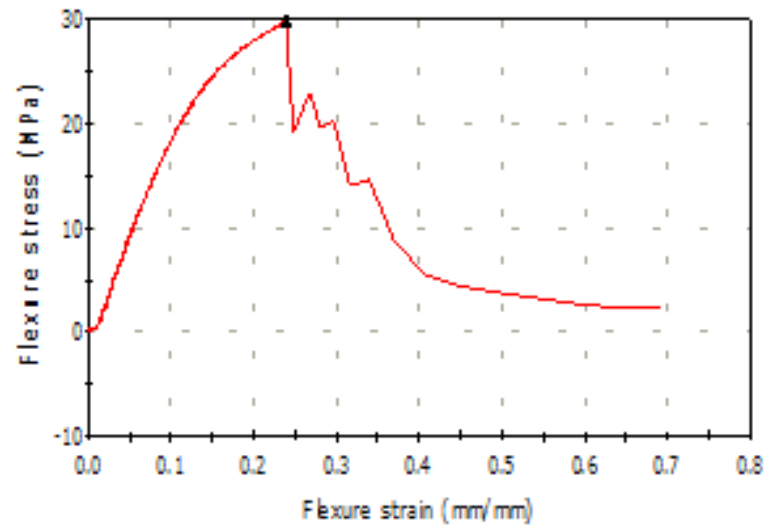

D

Figure 2: A. Showing Flexural Stres s and Strain of Sample 1. Revealed flexural strength $20.57 \mathrm{~N} / \mathrm{mm}^{2}$, load at break of 3.99N, modulus 180.24 MPa and elongation (ductility) of $69.76 \mathrm{~mm}$. B. Showing Flexural Stress and Strain of Sample 2. It had flexural strength $20.81 \mathrm{~N} / \mathrm{mm}^{2}$, load at break of $13.95 \mathrm{~N}$, modulus $250.52 \mathrm{MPa}$ and elongation(ductility) of 40.59 $\mathrm{mm}$. C. Showing Flexural Stres s and Strain of Sample 3. Shows flexural strength $34.43 \mathrm{~N} / \mathrm{mm}^{2}$, load at break of $32.82 \mathrm{~N}$, modulus $255.65 \mathrm{MPa}$ and elongation (ductility) of $66.81 \mathrm{~mm}$. D. Showing Flexural Stres s and Strain of Sample 4. It had flexural strength $29.91 \mathrm{~N} / \mathrm{mm}^{2}$, load at break of $14.86 \mathrm{~N}$, modulus $230.22 \mathrm{MPa}$ and elongation(ductility) of $43.25 \mathrm{~mm}$ 
Table 5. Showing the Thickness, Width, Energy at Break and Load at Yield

\begin{tabular}{|c|l|l|l|l|}
\hline S Sample & $\begin{array}{l}\text { Thickness } \\
(\mathrm{mm})\end{array}$ & $\begin{array}{l}\text { Width } \\
(\mathrm{mm})\end{array}$ & $\begin{array}{c}\text { Energy at Break } \\
(\text { Standard) } \\
(\mathbf{J})\end{array}$ & $\begin{array}{c}\text { Load at Yield (Zero } \\
\text { Slope) } \\
(\mathrm{N})\end{array}$ \\
\hline 1 & 10 & ---- & 1.80354 & -128.26384 \\
\hline 2 & 10 & ---- & 2.21020 & -129.73611 \\
\hline 3 & 10 & ---- & 6.95085 & -214.58303 \\
\hline 4 & 10 & ---- & 3.21809 & -186.43081 \\
\hline
\end{tabular}

Table 6: Showing Load at Break, Modulus, Flexure Load and Extension at Break

\begin{tabular}{|c|c|c|c|c|}
\hline & $\begin{array}{c}\text { Load at Break } \\
(\text { Standard) } \\
(\mathrm{N})\end{array}$ & $\begin{array}{l}\text { Modulus (Automatic) } \\
(\mathrm{MPa})\end{array}$ & $\begin{array}{c}\text { Load Flexure at break } \\
\text { (Standard) } \\
(\mathrm{N})\end{array}$ & $\begin{array}{c}\text { Flexure Extension } \\
\text { at break (Standard) } \\
(\mathrm{mm})\end{array}$ \\
\hline 1 & -3.98953 & 180.24946 & 3.98953 & 69.75626 \\
\hline 2 & -13.95001 & 250.52019 & 12.95001 & 40.59484 \\
\hline 3 & -32.81620 & 255.65332 & 32.81620 & 66.80907 \\
\hline 4 & -14.86060 & 230.21981 & 14.86060 & 43.25047 \\
\hline
\end{tabular}

Table 7: Showing Flexure Strain at Break, Flexure Stress at Break, Energy at Yield and Flexure Extension at Yield

\begin{tabular}{|c|c|c|l|l|}
\hline & $\begin{array}{c}\text { Flexure strain at } \\
\text { Break (Standard) } \\
(\mathrm{mm} / \mathrm{mm})\end{array}$ & $\begin{array}{c}\text { Flexure Stress } \\
\text { break(Standard) }\end{array}$ & $\begin{array}{l}\text { Energy at yield } \\
\text { (Zero slope) } \\
(\mathrm{J})\end{array}$ & $\begin{array}{c}\text { Flexure extension } \\
\text { at yield (Zero slope) } \\
(\mathrm{mm})\end{array}$ \\
\hline 1 & 1.05452 & 0.64003 & 1.02557 & 12.53687 \\
\hline 2 & 0.61368 & 2.23797 & 0.94334 & 11.22391 \\
\hline 3 & 1.00996 & 5.26464 & 3.31765 & 22.12000 \\
\hline 4 & 0.65382 & 2.38406 & 1.83023 & 15.82422 \\
\hline
\end{tabular}


Table 8: Load at yield, Flexure Strain and Stress at yield

\begin{tabular}{|c|c|c|c|}
\hline & $\begin{array}{c}\text { Load at yield } \\
(\mathrm{N})\end{array}$ & $\begin{array}{c}\text { Flexure Strain at yield } \\
(\text { Zero Slope) } \\
(\mathrm{mm} / \mathrm{mm})\end{array}$ & $\begin{array}{c}\text { Stress at yield (Zero } \\
\text { Slope) } \\
(\mathrm{MPa})\end{array}$ \\
\hline 1 & 128.26384 & 0.18952 & 20.57714 \\
\hline 2 & 129.73611 & 0.16967 & 20.81333 \\
\hline 3 & 214.58304 & 0.33439 & 34.42517 \\
\hline 4 & 186.43082 & 0.23922 & 29.90876 \\
\hline
\end{tabular}

Experimental Observation -sample 3 has highest flexural strength followed by 4,2 and 1 . The most flexural is sample 1. The highest modulus is sample 3. A verage Flexural strength $26.43 \mathrm{~N} / \mathrm{mm}^{2}$, load at break of $16.04 \mathrm{~N}$, modulus $229.16 \mathrm{MPa}$ and elong ation (ductility) of $55.1 \mathrm{~mm}$.

\subsubsection{Compression Test Result}

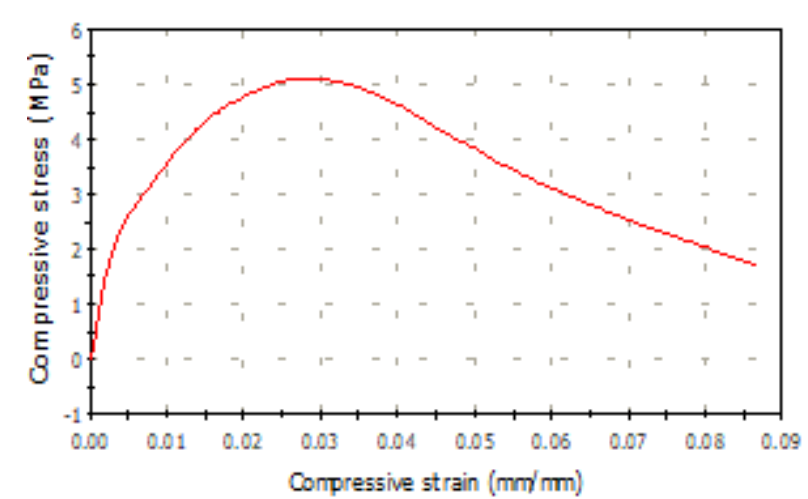

A

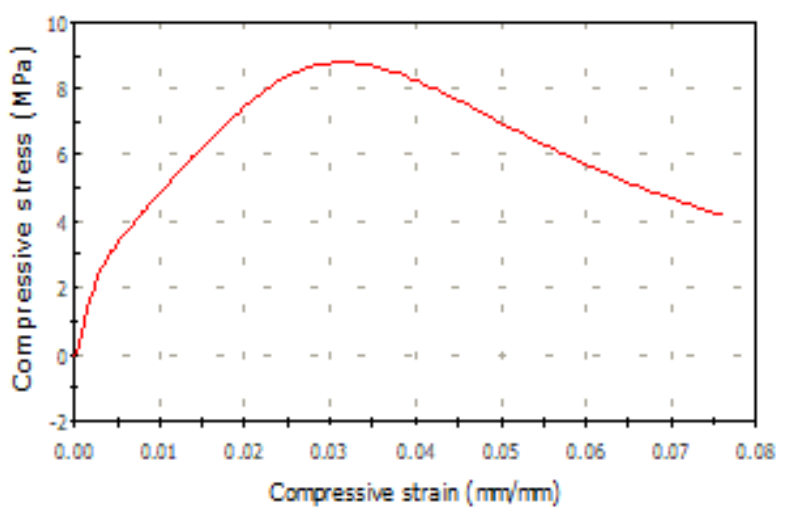

C

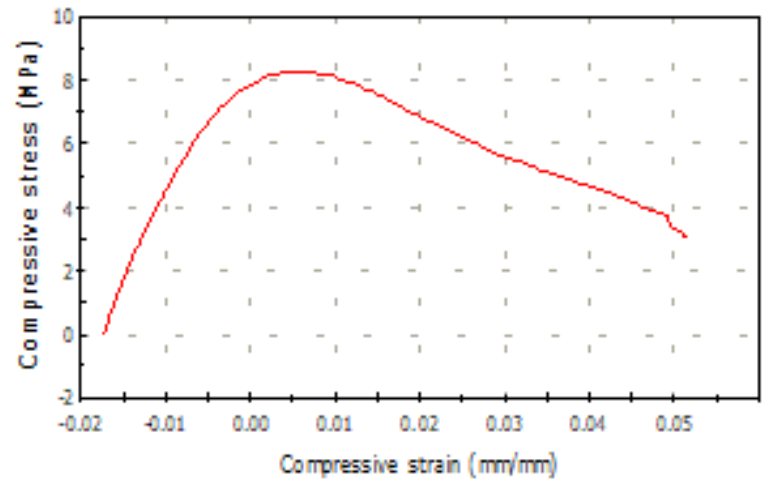

B

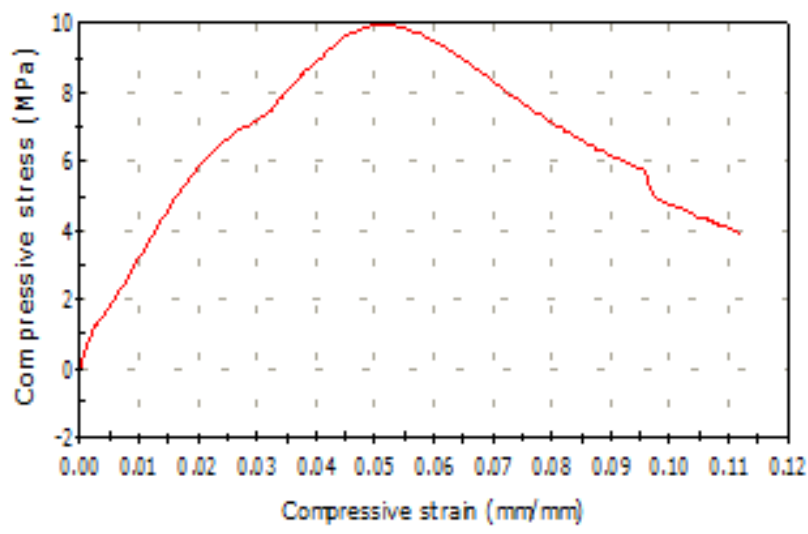

D

Figure 3: A. Showing Compressive Stress and Strain of Sample 1. It had compressive strength of 5.1MPa, compressive load at break of 135.87N, modulus 523MPa. B. Showing Compressive Stress and Strain of Sample 2. Compressive strength of 8.28MPa obtained, at compressive load at break of $242.89 \mathrm{~N}$, modulus 683.37MPa. C. Showing Compressive Stress and Strain of Sample 3. Had compres sive strength of 8.79MPa, compressive load at break of 330N, modulus 622.53MPa. D. Showing Compressive Stress and Strain of Sample 4. Had compres sive strength of 9.94MPa, compressive load at break of $309 \mathrm{~N}$, modulus 283.14MPa 
Table 9: Showing Compressive Extension, Compressive Strain, Compressive load and Compressive Stress at Break of Sample 1, 2,3 and 4 of Rattan Cane

\begin{tabular}{|c|c|c|c|c|}
\hline Sample & $\begin{array}{c}\text { Compressive } \\
\text { extension at break } \\
\text { (Standard) } \\
(\mathrm{mm})\end{array}$ & $\begin{array}{c}\text { Compressive strain at } \\
\text { break(Standard) } \\
(\%)\end{array}$ & $\begin{array}{c}\text { Compressive load at } \\
\text { break (Standard) } \\
(\mathrm{N})\end{array}$ & $\begin{array}{c}\text { Compressive stress at } \\
\text { break (Standard) } \\
(\mathrm{MPa})\end{array}$ \\
\hline 1 & 10.35031 & 8.62526 & 135.87352 & 1.73000 \\
\hline 2 & 6.15203 & 5.12669 & 242.88120 & 3.09246 \\
\hline 3 & 9.10000 & 7.58333 & 330.06693 & 4.20254 \\
\hline 4 & 13.40016 & 11.16680 & 309.04013 & 3.93482 \\
\hline
\end{tabular}

Table 10: Showing Energy and Extension at Break, Compressive Load and Compressive Strain at Maximum Compressive Extension of Cane samples

\begin{tabular}{|c|c|c|c|c|}
\hline s Sample & $\begin{array}{l}\underset{\text { Energy at }}{\text { Break }} \\
\text { (Standard) } \\
\text { (J) }\end{array}$ & $\begin{array}{l}\text { Extension at Break } \\
\text { (Standard) } \\
(\mathrm{mm})\end{array}$ & $\begin{array}{l}\text { Compressive load at } \\
\text { Maximum Compressive } \\
\text { extension } \\
\text { (N) }\end{array}$ & $\begin{array}{l}\text { Compressive strain at } \\
\text { Maximum Compressive } \\
\text { extension } \\
\text { (\%) }\end{array}$ \\
\hline 1 & 2.87794 & -10.35031 & 134.66585 & 8.66328 \\
\hline 2 & 3.75961 & -6.15203 & 240.88321 & 5.15169 \\
\hline 3 & 4.51703 & -9.10000 & 328.24210 & 7.61576 \\
\hline 4 & 6.99279 & -13.40016 & 307.82941 & 11.19675 \\
\hline
\end{tabular}

Table 12: showing Maximum Compressive Extension, Compressive Stress at maximum Compressive Extension, Area and Diameter of the Cane Samples

\begin{tabular}{|c|c|c|c|c|}
\hline s Sample & $\begin{array}{c}\text { Maximum } \\
\text { Compressive extension } \\
(\mathrm{mm})\end{array}$ & $\begin{array}{c}\text { Compressive stress at } \\
\text { Maximum Compres sive } \\
\text { extension } \\
(\mathrm{MPa})\end{array}$ & $\begin{array}{l}\text { Area } \\
\left(\mathrm{cm}^{2}\right)\end{array}$ \\
\hline 1 & 10.39594 & 1.71462 & 0.78540 & 10.00000 \\
\hline 2 & 6.18203 & 3.06702 & 0.78540 & 10.00000 \\
\hline 3 & 9.13891 & 4.17931 & 0.78540 & 10.00000 \\
\hline 4 & 13.43609 & 3.91941 & 0.78540 & 10.00000 \\
\hline
\end{tabular}


Table 13: Showing Modulus, Poiss on's Ratio, Compressive Load at Yield and Compressive Extension at Yield

\begin{tabular}{|c|l|l|l|l|}
\hline S Sample & $\begin{array}{l}\text { Modulus (Automatic) } \\
\text { (MPa) }\end{array}$ & $\begin{array}{c}\text { Poisson's } \\
\text { (Chord) }\end{array}$ & $\begin{array}{c}\text { Ratio } \\
\text { Yompressive load at } \\
\text { YN) }\end{array}$ & $\begin{array}{c}\text { Compressive } \\
\text { extension at Yield (Zero } \\
\text { Slope) } \\
(\mathrm{mm})\end{array}$ \\
\hline 1 & 523.00939 & ----- & 401.32556 & 3.30016 \\
\hline 2 & 683.36692 & ---- & 650.67346 & 0.65219 \\
\hline 3 & 622.53276 & ---- & 690.63397 & 3.75016 \\
\hline 4 & 283.13789 & ---- & 780.93927 & 6.10000 \\
\hline
\end{tabular}

Table 14: Showing Compressive Strain and Stress at Yield, Anvil Height and Thickness

\begin{tabular}{|c|c|c|c|c|}
\hline s Sample & $\begin{array}{c}\text { Compressive strain at } \\
\text { Yield (Zero Slope) } \\
(\%)\end{array}$ & $\begin{array}{c}\text { Compressive stress at } \\
\text { Yield (Zero Slope) } \\
(\mathrm{MPa})\end{array}$ & $\begin{array}{l}\text { Anvilheight } \\
(\mathrm{mm})\end{array}$ & $\begin{array}{l}\text { Thickness } \\
(\mathrm{mm})\end{array}$ \\
\hline 1 & 2.75013 & 5.10984 & 120.00000 & 10.00000 \\
\hline 2 & 0.54349 & 8.28463 & 120.00000 & 10.00000 \\
\hline 3 & 3.12513 & 8.79343 & 120.00000 & 10.00000 \\
\hline 4 & 5.08333 & 9.94323 & 120.00000 & 10.00000 \\
\hline
\end{tabular}

Experimental Observation - sample 4 had the highest compressive strength followed by 3,2 and 1 . The highest load resistance was shown by sample 3 and is followed to tail by 4, 2 and 1 . Average compressive strength is $8.02 \mathrm{MPa}$, compressive load at break of $254.44 \mathrm{~N}$ and modulus 528.01MPa.

\subsubsection{Gait Analysis}

The reference Foot leng th on the first slide was $8 \mathrm{~cm}$ and this was maintained and used to ensure accuracy throughout the analy sis at assumed height of deformation for the prosthetic foot meas ured on loading weight of the body transfenred to the foot device.

3.1.5.1 Terminal Swing showed chosen (normal) height as the amputee was about to load the prosthetic foot device and hence no deformity at a height $=8 \mathrm{~cm}$.

3.1.5.2 Heel Strike showed height of $8 \mathrm{~cm}$ and immeasurable deformity of $0 \mathrm{~cm}$ as loading commenced heel strike positioned.

3.1.5.3 Early Stance: At early stance, the amputee performed Toe off of the contra lateral limb less anchored weight, and load was on the prosthetic foot to produce deformity of $0.3 \mathrm{~cm}$ and reduced height of $7.7 \mathrm{~cm}$ as less inclined load is distributed possibly even.

3.1.5.4 Mid Stance: At mid stance, the amputee performed a single stance on the prosthetic limb with maximum weight and load excited. Deformity $0.6 \mathrm{~cm}$ produced reduced height to $7.4 \mathrm{~cm}$. 
3.1.5.5 Early Toe Off/Terminal Stance: At this stage, the limb is at maximum dorsiflexion moment in preparation for the propulsive toe off. Weight restoration is compensatory to height $8 \mathrm{cmas}$ deformity is off to give $0 \mathrm{~cm}$.

3.1.5.6 Late toe off: At this stage Toe off is almost complete. The Heel is off the ground. The Toe region presses into the ground to generate the propulsive force of deformity $0.3 \mathrm{~cm}$ as if weight draws on height from $8 \mathrm{~cm}$ to $7.7 \mathrm{~cm}$.

\section{DISCUSSION}

In order to meet with the increasing demand of prosthetics by amputees in the globe, numerous types of natural and artificial materials are often used in rehabilitation technology. Common materials used in prosthetics are such that conform to standard requirements [35] and they are various types of metals and plastics. Depending on region of the globe, traditional materials for special prosthetic foot is as elsewhere [14] to include combination of metal and plas tic, plant and animal preparatory, metallic alloys and hydrocarbon. Therefore in this study, the biomechanical properties of rattan cane plant were randomly searched among four sample stems species selected without consideration to degree of dryness to obtain enhanced feet in need nowadays [15].

The biomechanical properties of phyto-biomaterials often reveal the structural formation and possibly serve as one of the basic factors to the strength and biocompatibility. Consequently application of biological materials in biomaterial science and biomedical en gineering follow after concrete analysis of structure, biomechanical, and molecular compositions especially when rehabilitation technology focuses on pliability. Rattan cane being one of such materials had four samples from different stems selected and same were subjected to biomechanical analysis. Thus findings were recorded as in figures 1 to 3 and tables 1 to 14 . This type of study design and to the extent of analy sis carried out is not recorded about any phytobiomaterial to our knowledge in rehabilitation engineering save for metals and hydrocarbon [1,16 and [17] and the work on physical property [18] in combination for civil engineering [36]. Also elsewhere rattan wood had been used in combination with certain elements as calcium and other to form bone subjected to implantation trial on pigs and other animals in 2010.

Though this study is not holistic when molecular composition and structural arrangement is core consideration. The findings revealed that rattan cane wood may have pliability which possibly is related to stuff arrangement and molecular biochemistry [37]. Could these physical properties be the reasons why the cane lack the ability to retain water molecules when left at atmospheric condition in the open field as observed in this study? Or could it be the same property observed add up to the 20 channels structure that in spired industrialist to use rattan specie for oil wicking and avotion [38-39]. These as sertions were made plausible when load is leveled at standard break limit on the four samples with varied outcomes as in all the figures and tables herein.

The biomechanical analy sis was conducted to obtain the ultimate tensile strength (UTS) of rattan cane. The revelation was minimum range of $6.0 \mathrm{~N} / \mathrm{mm}^{2}$ and maximum of $11.5 \mathrm{~N} / \mathrm{mm}^{2}$ with ultimate average possible standard of $8.68 \mathrm{~N} / \mathrm{mm}^{2}$ obtained from four randomly s elected s amples at different dryness when on average load at break po int $396.66 \mathrm{~N}$ weighed (Figures 1-3). Though a study have shown that s pruce with $16 \%$ mois ture has maximum compres sive strength reduced by $50 \%$ [40] but rattan cane was not one of the woods considered for the standard of $13 \mathrm{~N} / \mathrm{mm}^{2}$. This suggests that rattan cane when at ultimate tensile strength range and on discrete differential load at break point ranges from $236.6 \mathrm{~N}$ to $668.18 \mathrm{~N}$ (as given by four samples), can sustain modulus range of 573.63Mpa to $1434.74 \mathrm{MPa}$ at producible ductility range of $5.8 \mathrm{~mm}$ to $16.25 \mathrm{~mm}$. Therefore an approximate average ductility of $9.50 \mathrm{~mm}$ length of rattan cane can only bepossible if weight at break point of $396.66 \mathrm{~N}$ exert UTS $8.68 \mathrm{Nmm}^{2}$ and modulus $1119 \mathrm{MPa}$. Consequently the four samples characteris tically showcased tensile strain and stress measurable as shown in Table 1 as in a work [41] and, that average of $0.10556 \mathrm{~mm} / \mathrm{mm}$ and $5.05088 \mathrm{~mm} / \mathrm{mm}$ distributed respectively when exceeded, irrespective of molecular structural cohesion force, rattan cane damage results as in a study [42]. Such tensile strain absorption power has not been recorded of plant biomaterial in any literature to our knowledge save possibly for raffia rope in furniture making [43]. This outcome seems comparable to metallic springs and that obtainable fromcertain metals used in prosthetic limbs fabrication even composite materials [44]. Also records exist that informed the use of rattan cane in civil and structural engineering works, ancient armory making like swords and shield for Art and combats [45-49], even in house hold furniture. In en gineering tensile exten sion property is said to sustain, conserve, and encourage structural rearrangement for energy dis tribution through sudden change in configuration as load is increased. From this study, rattan cane has show strength at load break point standard often similarly observed with metals like aluminum, steel, titanium and others. Therefore energy yields at zero slope found to be between zero to $1.87295 \mathrm{~J}$ is retained by rattan cane (Table 2) and is not that responsible for bond molecular structure and sudden configuration change. This energy was searched for as in Table 5 but failed to tally, in that carbon- nitrogen-hydrogen bonding was not aimed at. More work is needed to confirm the molecular structure binding energy of rattan cane. Again, the final area to area reduction is constant at $78.53982 \mathrm{~mm}^{2}$ for true stress at yield and is in the range of zero to 
8998059.82947MPa for rattan cane (Table 4). This remained consistent throughout the whole 8cm length (test chosen length) of rattan cane for lower limb prosthetic foot fabricated.

Flexural strength analysis of rattan cane revealed strain and stress demonstration and absorption when load at various break ratio points were exerted as in all the Figures. An average flexural strength $26.43 \mathrm{~N} / \mathrm{m} 2$ was expres sed when load at break of $16.04 \mathrm{~N}$ was given to rattan cane and modulus $229.16 \mathrm{MPa}$ inclusive resulted to ductility of length $55.1 \mathrm{~mm}$. The result further revealed that flexural stress and strain ranges 0.16967 to $0.33439 \mathrm{~mm} / \mathrm{mm}$ respectively and modulus 20.57714 to $34.42517 \mathrm{MPa}$ at zero slope (Tables 5-8) can possibly support multi-shaping with rattan cane. The insight adduced in this case is that at UTS, flexural streng th encourages energy distribution (from the skeletal muscles) [41] along the entire length of rattan cane first to allow pliability (at which occasion multi-shaping can be possible) as load at break point applies. Hence, energy dispersion along the length, area, and possible shapes orig in ated during fabrication (in the case of prosthetic foot and structural engineering) do occur. This is retained even when load at break points is incident on planted biomaterial [42- 43]. This was made sustainable by the res ults fromcompressive strength at load break points (Figures). This behavior is comparable to that of ferrous irons which gives elongation even without increased force and still remain durable [44].

It is obvious from the results of biomechanical test that rattan canehas the required parameters necessary to engineering weight bearing. Also that compression at various limits stress and strain has resilientenergy conservation for shear in time. Again, the choice of rattan cane was enhanced by the fact that the compressive load yield at zero slope of $690.63397 \mathrm{~N}$ which when above gives longevity over time, was well compensated by the $4.17931 \mathrm{Mpa}$ and $7.61576 \mathrm{Mpa}$ modulus. Compres sive stress and strain had maximum compressive extension at area of $0.078540 \mathrm{~cm}^{2}$. But when average maximum load at point extension of $328.24210 \mathrm{~N}$ yield $-9.10000 \mathrm{~mm}$ length it can be related to break standard as energy at break is $4.51703 \mathrm{~J}$ to shear. These constituted to the firm turf consis tency observed throughout fabrication and gait analysis in other studies [50-51].

Reference height of $8 \mathrm{~cm}$ was chosen during the gait analysis to ensure easy and accuracy in the measurement of deformity height that may occur on the prosthetic foot on load. The body weight of patient generated energy on the rattan cane prosthetic footresulting in dynamic ripple dis tribution and partial retention to allow terminals wing, heel strike, early and mid stance, early toe off/terminal stance and late toe off [52].

At terminal swing the amputee weight had full resolution and load not applied, hence there is no deformity on the dynamic rattan cane prosthetic foot. Consequently there is reduction on vertical and horizontal height even at heel strike and on leg swing set which would not happened if there was reinforcement as is also shown in studies [53- 54]. During early and mid stances there were deformities of $0.3 \mathrm{~cm}$ and $0.6 \mathrm{~cm}$ length short observed respectively? These were because of less inclination and full weight exertion on the device. The deformities from $8 \mathrm{~cm}$ to $7.7 \mathrm{~cm}$ and $7.4 \mathrm{~cm}$ were restored at early toe off/terminal stance when there is dorsiflexion moment in preparation for propulsive toe off as oxygen uptakeby the Amputeeincreases [55]. At late toe off when the heel is off the ground there is energy instance conservation [56], and this is comparable to a study where $1 \mathrm{~mm}$ deformity in height was recorded [57]. The dynamic (springing) revelation can only be explained in consideration of biomechanical factors of rattan cane as recorded above and is in total agreement with Hooke's law. Also studies have revealed that inflexibility contributes too little energy conservation and dis tribution [[5558].

The gait analysis results support the biomechanical findings fromrattan cane than biomolecular structural arrangement in that load was well bear and shear while energy was transmitted and res tored along the entire device, to support the multishape constructed and give balance comparable to basic gait parameters [59]. Therefore rattan cane plant has shown dynamism, stiffness, pliability to cushion the lower limb. Absorption and transmis sion of energy supported performance of gait at undetermined or specific dryness state. It is pos sible that rattan cane can be used for lower-limb prosthetics and may require re-enforcement [58] at high stress areas where energy retention is needed for compensation as in some studies [60]. Rattan cane is readily available locally and can easily be processed at fabrication work places to obtain cheap prosthetic limb.

\section{CONCLUSIONS}

The design for dynamic response was in the curves made with the cane which when compressed via patient weight/loading will flatten, thereby storing potential energy. This energy can consequently be released to the load in accentuation during toe off and helps to reduce the amount of energy required for $g$ ait. The gait analysis clearly shows the dynamic nature of the foot during patient gait. The prosthetic foot can therefore replicate the dynamic response found in carbon fiber feet at a very cheap price. Active patients can now afford a dynamic res ponse foot which quality performance is comparable.

The mechanical test however needs more research as the results from the mechanical tests were very low and competitively high with same s pecies of rattan cane when compared to with previously resembling studies. The study has 
shown that rattan cane possesses the tensile and compression strength good enough to be employed as bio -engineering material in medicine specialty.

More works are needed on rattan cane to ascertain the reason for the low and high mechanicaltest readings obtained from four species as to understand the effect of drying on procession and construction.

\section{REFERENCES}

[1] Klasson B L, "Carbon fiber and fibril lamination in Prosthetics and orthotics: some basic theory and practical advice for the practitioner", POI, vol.19, pp. 74-91, 1995.

[2] Alam M, Y Furukawa, "Cane Enterprises as Family business in Bangladesh: A case Study", Electronic Journal of Family Business Studies, vol. 3, no. 2, 2009.

[3] Lucas E B, B I O Dahunsi, "Harvesting, processing and utilization of rattan canes in Western Nigeria", Journal of Southern African Forestry, vol. 202, pp. 37-44, 2004a.

[4] Abasolo WP, Yoshida M, Yamamoto H, Okuyama T, "Influence of cell type on the thermal softening of Calamus merrillii Becc", Journal of International Association of Wood Anatomist, vol. 26, pp. 363-374, 2005.

[5] A O Olorunnisola A, Pitman H, Manfield-William, "Hydration characteristics of cement-bonded composites made from rattan cane and coconut husk", Journal Bomboo and Rattan, vol. 4, no. 2, pp. 193-201, 2005.

[6] Karki J B S, Karki M, "Bamboo production, use and trade in Eastern Nepal: A Case Study, In The Role of Bamboo, Rattan, Medicinal Plants in Mountain Development", Proceedings of the Ins titute of Forestry, Pokhara Nepal. INBAR Technical Report, no. 15, pp. 144-155, 1996.

[7] Blazkova L, Jenicek V, "Rattan production and trade", Agricultura Tropica etSubtropica, vol. 39, pp. 1-7, 2006.

[8] Meitram B, G J Sharma, "Rattan res ources of Manipur ; species diversity", Journal of Bamboo and Rattan, vol. 4, pp. 399-419, 2005.

[9] Arinana Hinsui J, Ignatius B, Kronseder K, K"arkk" ainen, J Pingoud P, Sandra E, "Non timber forest products in Northern Thai-land", 2008 Available http://www.mm.hels inki.fi/MMEKO/VITRI/forrsa/RE2Course\%20and\%20workshop\%20proceedings/report/Group5 Report. pdf accessed July 4, 2009.

[10] Widayati A, Jone S, Carlis le B, "Accessibility Factors and Conservation Forest Designation Affecting Rattan Cane Harvesting in Lambus ango Forest, Buton, Indonesia”, Human Ecology, vol. 38, pp. 731-746, 2010.

[11] Belcher B, "A production to consumption systems approach: les sons fromthe bamboo and rattan sectors in Asia. In: E. Wollenberg and A. Ingles (eds). Incomes from the forest: methods for the development and conservation of forest products for local communities", CIFOR/IUCN, 1999.

[12] Burkill I H, "A dictionary of the economic products of the Malay Peninsula ”, Crown Agents, London, vol. 2, 1935.

[13] Corner E J H, “The Natural His tory of Palms”, W iedenfield and Nicols on (Editions), London, 1966.

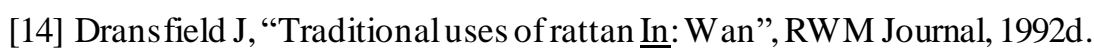

[15] Dransfield J, “A manual of the rattans of the Malay Peninsula”, Malayan Forest 1979.

[16] Sunderland T C H, “The Rattans of Rio Muni, Equatorial Guinea: Utilis ation, Biology and Distribution”, Report to the Proyecto Conservación y Utilización Regional de los Ecosistemas Forestales (CUREF) - Fondo Europeo de Desarrollo - Proyecto, No.6- ACP-EG 020. 1998.

[17] Johnson D V, “Non-wood forest products: Tropical Palms”, Food and Agriculture Org anization, Rome, 1997.

[18] Jensen J S, Raab W, "Clinical testing of vulcanized Jaipur rubber feet for transtibial amputees in low-income countries", Prosthetics and Orthotics International, vol. 30, no. 3, pp. 225-236, 2006.

[19] Klute G K, Kallfelz C F, Czemeck J M, "Mechanical Properties of Prosthetic Limbs: Adapting to the Patient", Journal Rehabilitation Research \& Devlopmente., vol. 38, no.3, pp. 299-307, 2001. 
[20] Pierre Cherelle, Victor Grosu, Manuel Cestari, Bram Vanderborght, Dirk Lefeber, "The AMPFoot, new generation propulsive prosthetic feet with explosive motion characteristics: design and validation", Bio Med Eng On Line, vol. 15, pp. 145, 2016. DOI 10.1186/s 12938-016-0285-8

[21] Bowker H K, Michael J W, "Atlas of limb prosthetics: Surgical, Prosthetic and Rehabilitation Principles”, American Academy of Orthopedic Surgeons. $2^{\text {nd }}$ Edition, 1992.

[22] Rosalam C M, Rahinah I, Parida T, "Natural bases biocomposite material for prosthetic socket fabrication”, Alam cipta., vol. 5, no.1, pp. 27-35, 2012.

[23] Lucas EB, Dahunsi B IO, "Characteristics ofThree Western Nigerian Rattan Species in Relation to Their Utilization as Construction Material", Journal of Bamboo and Rattan, vol. 3, pp. 45-56, 2004b.

[24] Saito M, Sawamura S, Carroll B, Nakayama H, and Yuki M, "Mass produced prosthesis uses pultruded FRP", Modern Plastics, vol. 74, no.7, pp. 175, 1997.

[25] von Mises R, "Die mechanik der festen körper in plastisch deformierten zustand. Nachrichten Göttingen Akademie Wis senschaftliche", Math-physik, vol. 1, pp. 582-592, 1913

[26] Nikos P Andrianopoulos, Vasileios M Manolopoulos, "Elastic strain energy density decomposition in failure of ductile materials undercombined torsion-tension", International Journal of Mechanical and Materials Engineering, vol. 9, pp. 16, 2014

[27] Andrianopoulos NP, Manolopoulos VM, "Can Coulomb criterion be generalized in case of ductile materials? An application to Bridgman experiments”, International Journal of Mechanical Sciences, v 54, p 241-248, 2012

[28] Andrianopoulos NP, Manolopoulos VM, Boulougouris VC, "Considerations on failure surfaces in brittle, non linear elastic materials", Patras: 8th International, Congress on Mechanics, HSTAM2007, 2007

[29] Christensen RM, "Yield functions/failure criteria for isotropic materials" Proceedings of the Royal Society of London, vol. 453, pp. 1473-1491, 1997

[30] Christensen R M, "A two-property yield, failure (fracture) criterion for homogeneous is otropic materials", Journal of Engineering Materials and Technology, vol. 126, pp. 45-52, 2004

[31] Andrianopoulos NP, Manolopoulos VM, Dernikas IT, "Coulomb failure surfaces in ductile nonlinear elastic materials", Patras: 1st International Conference of Engineering Against Fracture, 2008

[32] Christensen RM, "Failure mechanics - part I: the coordination between elasticity theory and failure the ory for all is otropic materials", Journal of Applied Mechanics, vol. 81, no. 8, pp. 1-7, 2014

[33] Andrianopoulos NP, Boulougouris VC, "Failure by fracture or yielding in strain hardening materials according to the T-criterion", Engineering Fracture Mechanics, v 47, p 639-651, 1994

[34] Andrianopoulos and Manolopoulos: Elastic strain energy density decomposition in failure of ductile materials under combined torsion-tension. International Journal of Mechanical and Materials Engineering, vol. 9, pp. 16, 2014

[35] Rehab Tech, "Summary information on prosthetic standards", Journal Rehab Research and Development, vol. 28, no.2,pp. $79-90,1995$

[36] Lucas EB, Dahunsi B I O, "Bond Strength in Concrete of Canes from Three Rattans Species", Journal of Applied Science, Engineering and Technology, vol. 4, pp. 1-5, 2004

[37] Seungjion Chung, "Us eofplant-derived sorbents for wicking oil and stimulating biodegradation in wetland", A dis sertation to the division of research and advanced studies University of Cincinnati, Department of Civil and EnvironmentalEngineering, College of Engineering. 2009. https//scholar.google.com/scholar_lookup?

[38] Adebajo M O, Frost RL, Kloprogge J T, Carmody O, Kokot S, "Porous materials for oil spill cleanup: a review of synthesis and absorbing properties", Journal of porous materials, vol.10, pp. 159-170, 2003

[39]Annunciado T R, Sydenstricker T HD, Amico S C, "Experimental investigation of various vegetable fibers as sorbent materials for oil spills", Marine Pollution Bulletin, vol50, p1340-1346, 2005

[40] John W Cumming, Joseph McLaugh lin, "The thermogravimetric behavior of coal", Thermochimica Acta, vol. 57, pp. 253-272, 1982

[41] MahzuzHM A, Ahmed M,Uddin M K, Hossain M M, Saquib N, "Determination of Tensile Stress and Bond Stress with Concrete of a Rattan (Calamus guruba)", Scholars Journal of Engineering and Technology, vol. 1, pp. 39-43, 2013.

[42] Kankam, C K, "Raffia Palm-Rein forced Concrete Beams”, Materials and Structures, vol. 30, pp. 313-316, 1997. 
[42] Ali ARM, Hashmi MSJ, “Theoretical and experimental results of the elastic-plastic res ponse of a circular rod subjected to non-proportional combined torque and tension loadings", ARCHIVE Proceedings of the Institution of Mechanical Engineers Part C Journal of Mechanical Engineering Science 1989-1996, vols 203-210, no. 213(3), pp. 251261, 1999

[43] Barry D.A and CP C, "Composite materials for orthotics and prosthetics", Prosthetics and Orthotics, vol. 40, no. 4, pp.35-43, 1987.

[44] Walke K M, Pandure PS, "Mechanical properties of materials used for prosthetic foot: A Review', IOSR Journal of mechanical and Civil Engineering, e-ISSN; 2278-1684, Pp.61-65, 2017.

[45] Krieger, Herbert N, "The collection of primitive weapons and armor of the Philippine Islands in the United States National Museum, Smithsonian Institute”, National Museum Bulletin, United States, pp 137, 1926:

[46] Zmitrewicz R J, Neptune R R, Sasaki K, "Mechanical energetic contributions fromindividual muscles and elastic prosthetic feet during symmetric unilateral transtibial amputee walking: A theoretical study", Journal Biomechanics, vol. 40, no. 8, pp. 1824-1831, 2007.

[47] Hafner B J, Sanders J E, Czerniecki J and Fergas on J, "Energy storage and return prostheses: Does patient perception correlate with biomechanical analysis?", Clinical Biomechanics. Bristol Avon, vol. 17, no. 5, pp. 325-344. 2002a.

[48] Ehara Y, Beppu M, Nomura S, Kunimi Y and Takahashi S, "Energy storing property of so-called energy-storing prosthetic feet", Achieve Physics and Medical Rehabilitation, vol. 74, no.1, pp.68-72, 1993.

[49] Rakesh B., "The Jaipur foot and the Jaipur prosthesis”, Indian J Orthop. Vol.53, no. 1, pp. 5 - 7, 2019.

[50] Al-kazraji K, Kadhim J, Ahmed P S, "Tensile and fatigue characteristics of lower limb pros thetic socket made from composite materials", International Conference on Industrial Engineering and OP Management, Turkey, 2012.

[51] Bowen J., Haus sele J and Gonzalez R., "A low cost customizable pros thet ic foot with energy return capabilities", P and Oopen Journal, vol. 2, no. 1, pp.1, 2018.

[52] Postema K, Hermens FU and Vries J, "Energy storage and release of prosthetic feet, part 1: Biomechanical analysis related to user benefit", Pros thetic and Orthoptics International., vol. 21, pp. 17-27, 1997.

[53] Agustinus P I, Frans J D, Fanando F, Tommy A, "Mechanicalcharacteristics of rattan reinforced fiberglass and epoxy composite for shank prosthesis application", Proceeding of the Innovation in Polymer Science and Technology IPST2011, pp. 63-70, 2016.

[54] Agustinus Purna Irawan, Tresna P Soemardi, K K, Widjajalaksmi,

Agus HS Reksoprodjo, "Gait Analysis Of The Prosthesis Prototype Made From The Natural Fiber Reinforced Composite", Proceedings, APCHIERGOFUTURE, UdayanaUniversity Press, pp. 39-43. 2010. ISBN No: 978-602-8566-85-8

[55] Vincent Gremeaux, Marwa Iskander, Gaelle Deley, Dominic Perennou and Sean-Marie Casillas, "Comparative Analysis of Oxygen Uptake in Elderly Subjects Performing two Walk Tests: the six-minutes' walk test and the 200-m fast walk test", Clinical Rehabilitation, vol. 22, no. 2, pp. 162-168, 2008.

[56] Hafner B J, Sanders J E, Czerniecki J M, Fergas on J, “Transtibial energy storage-and-return prosthetic devices: A review of energy concepts and a proposednomenclature", Journal Rehabilitation Research Development, vol. 39, no. 1, pp. 1-11, 2002b.

[57] Francis J Trost, "Energy storing feet", Journal of the Association of Children's P and OClinics, vol. 24, no. 4, pp. 82$101,2000$.

[58] Tommy Oberg, Alek Karsznia and Kurt Oberg,"Basic gait parameter: reference data for normalsubject, 10-79 years of age", Journal of Rehabilitation Res earch \& Development, vol. 30, no. 2, pp. 210-223, 1993.

[59] Agustinus Purna Irawan, Tresna P Soemardi, K K Widjajalaksmi, Agus H S Reksoprodjo, "Tensile and Flexural Strength of Ranie Fiber reinforced Epoxy Composites for socket Prosthesis Application", International Journal of Mechanical and Materials Engineering, vol.6, no.1,pp.46-50, 2011.

[60] Kahtan Al-Khazraji, Jawad Kadhim, Payman Sahbah Ahmed, "Tensile and Fatigue Characteristics of Lower-Limb Prosthetic Socket Made from Compos ite Materials", Proceedings of the 2012 International Conference on Industrial Engineering and Operations Management Istanbul, Turkey, pp. 847-852, 2012. 